\title{
History of the Public/Private Distinction
}

\section{Citation}

Morton J. Horwitz, History of the Public/Private Distinction, 130 U. Pa. L. Rev. 1423 (1982).

\section{Published Version}

http://scholarship.law.upenn.edu/penn_law_review/vol130/iss6/6/

\section{Permanent link}

http://nrs.harvard.edu/urn-3:HUL.InstRepos:12991700

\section{Terms of Use}

This article was downloaded from Harvard University's DASH repository, and is made available under the terms and conditions applicable to Other Posted Material, as set forth at http:// nrs.harvard.edu/urn-3:HUL.InstRepos:dash.current.terms-of-use\#LAA

\section{Share Your Story}

The Harvard community has made this article openly available.

Please share how this access benefits you. Submit a story.

\section{Accessibility}




\section{THE HISTORY OF THE PUBLIG/PRIVATE DISTINCTION}

\section{MORTon J. HoRwITZ $\dagger$}

The distinction between public and private realms arose out of a double movement in modern political and legal thought. On the one hand, with the emergence of the nation-state and theories of sovereignty in the sixteenth and seventeenth centuries, ideas of a distinctly public realm began to crystallize. ${ }^{1}$ On the other hand, in reaction to the claims of monarchs and, later, parliaments to the unrestrained power to make law, there developed a countervailing effort to stake out distinctively private spheres free from the encroaching power of the state. ${ }^{2}$ Natural rights theories were elaborated in the seventeenth century for the purpose of setting limits on state power, both over property and religious conscience. Rights theories were therefore not only efforts to incorporate into law what one writer has called a philosophy of "possessive individualism," 3 but also to provide an important basis for arguing for religious toleration.

One can trace the emergence of a distinctively public realm in various legal doctrines. By the late medieval period, for example, English law had already begun to draw a distinction between two different roles of the monarch as landowner. First were the lands the King held as feudal lord. These he could alienate as private property. But, increasingly, English law defined a second category of crown lands-in essence, public lands-which he could not alienate. Here we see an example of the gradual emergence of a distinctively public realm, which in the field of crown ownership of land finally crystallized in seventeenth century struggles over the King's power to alienate land between high and low watermark. 4

Taxation provides a fascinating example of the emergence of the public/private distinction. As late as the sixteenth century, English judges still analyzed taxation, not as an exaction by the

† Professor of Law, Harvard University. A.B. 1959, College of the City of New York; Ph.D. 1964, LL.B. 1967, Harvard University. Member, Massachusetts Bar.

i See D. Hanson, From Kingdom to Commonwearth 1-19 (1970).

2 See J. Appleby, Economic Thought And Ideology In Seventeenth-CenTURY ENGLAND 62-63 (1978). See generally J. Gough, FundaMENTaL Law IN Englise Constrtutional History (1961); C. McPherson, The Polrtical Theory of Possessive Individuajism (1970).

3 C. McPherson, supta note 2.

4 See D. Hanson, supra note 1 , at 143-46. 
state but as a private gift from the donor-the taxpayer. Parliament was thought to have simply arranged this consensual private transaction. ${ }^{5}$ Only with the development of theories of sovereignty in the seventeenth century did taxation begin to be understood as part of public law.

Another set of issues illustrates the same point, highlighting how recently it was that a distinctively public realm came to be a generally understood part of political and legal consciousness. Until the nineteenth century, lawsuits involving the removal of a public official from office were analyzed more frequently than not as questions of property. The officeholder often successfully claimed a property interest in the office from which he could not be divested. ${ }^{\circ}$

So we see, on one side, that it was only gradually that English and American law came to recognize a public realm distinct from medieval conceptions of property. And equally gradually legal doctrines developed the idea of a separate private realm free from public power.

Although one can find the origins of the idea of a distinctively private realm in the natural-rights liberalism of Locke and his successors, only in the nineteenth century was the public/private distinction brought to the center of the stage in American legal and political theory. Before this could occur, it was necessary to undermine an earlier tradition of republican thought that had closely identified private virtue and public interest. ${ }^{\text {? }}$

The emergence of the market as a central legitimating institution brought the public/private distinction into the core of legal discourse during the nineteenth century. ${ }^{8}$ Although, as we have seen, there were earlier anticipations of a distinction between public law and private law, only the nineteenth century produced a fundamental conceptual and architectural division in the way we understand the law. One of the central goals of nineteenth century legal thought was to create a clear separation between constitutional, criminal, and regulatory law-public law-and the law of private transactions-torts, contracts, property, and commercial law.

5 Lampson, Some New Light on the Growth of Parliamentary Sovereignty: Wimbish versus Taillebois, 35 AM. Pol. Scr. Rev. 952 (1941).

6 W. Nelson, Americanization of the Common Law 125 (1975); Nelson, Officeholding And Powerwielding: An Analysis of the Relationship Between Structure And Style In American Administrative History, 10 LAw \& Soc'y REv. 187, 194-95 (1976).

7 G. Wood, The Creation of the American Republic, 1776-1787, at 53-65, 608-10 (1969).

8 The classic work is K. Polanyi, The Great Transformation (1944). See generally P. Atryaf, The Rise ANd Fall OF Freedom OF Contract 226-31 (1979). 
Let me offer some illustrations. Among the most famous is the entirely novel separation between public and private corporations in the Dartmouth College Case, ${ }^{9}$ decided in 1819. Its purpose-certainly the purpose of Justice Story's famous concurring opinion-was to free the newly emerging business corporation from the regulatory public law premises that had dominated the prior law of corporations, whether municipal or trading corporations; both of which were regarded as arms of the state.

Another more all-encompassing example is the effort of nineteenth century thinkers to contractualize-that is, to "privatize"-a host of common law doctrines that had previously served to regulate bargains. The watering-down of doctrines like the rule that equity will not enforce unfair contracts was inspired by the idea that contract is an entirely private institution between consenting individuals in which the state should have no interest. ${ }^{10}$ By 1850 , it was common for courts to permit parties to contract out of common law duties, which only one generation earlier had been regarded as beyond their power to alter. ${ }^{11}$

A final example of the persistent effort of late nineteenthcentury legal thinkers to create a sharp distinction between public and private law was the movement to eliminate punitive damages in tort. Because the purpose of punitive damages was to use the tort law to regulate conduct, not merely to compensate individuals for injuries, their imposition was regarded as a usurpation of the public law functions of the criminal law. Several states abolished punitive damages on the grounds that combining public and private law functions was an unhealthy and dangerous business. ${ }^{12}$

What were the concerns that created a virtual obsession with separating public and private law, both conceptually and practically, during the nineteenth century? Above all was the effort of orthodox judges and jurists to create a legal science that would sharply separate law from politics. By creating a neutral and apolitical system of legal doctrine and legal reasoning free from what was thought to be the dangerous and unstable redistributive tendencies of democratic politics, legal thinkers hoped to temper the problem of "tyranny of the majority." Just as nineteenth-century political economy elevated the market to the status of the paramount insti-

9 Trustees of Dartmouth College v. Woodward, 17 U.S. (4 Wheat.) 518, 559, 669-73 (1819).

10 See generally P. ATTYAH, supra note 8.

II M. Horwitz, The Transformation of American Law 201-07 (1977).

12 See, e.g., Murphy v. Hobbs, 7 Colo. 541, 5 P. 119 (1884); Fay v. Parker, 53 N.H. 342 (1872). 
tution for distributing rewards on a supposedly neutral and apolitical basis, so too private law came to be understood as a neutral system for facilitating voluntary market transactions and vindicating injuries to private rights. The hostility to statutes expressed by nineteenth-century judges and legal thinkers reflected the view that state regulation of private relations was a dangerous and unnatural public intrusion into a system based on private rights.

The sharp distinction between public and private began to come under attack in reaction to the Supreme Court's 1905 decision in Lochner $v$. New York, ${ }^{13}$ constitutionalizing freedom of contract. For the next thirty years, the most brilliant and original legal thinkers America has ever had devoted their energies to exposing the conservative ideological foundations of the public/private distinction. Culminating in the Legal Realist Movement of the 1920's and 1930's, judges such as Holmes, Brandeis, and Cardozo and legal theorists such as Roscoe Pound, Walter Wheeler Cook, Wesley Hohfeld, Robert Lee Hale, Arthur Corbin, Warren Seavey, Morris Cohen, and Karl Llewelyn devoted themselves to attacking the premises behind the public/private distinction. ${ }^{14}$ Paralleling arguments then current in political economy, they ridiculed the invisiblehand premise behind any assumption that private law could be neutral and apolitical. All law was coercive and had distributive consequences, they argued. It must therefore be understood as a delegation of coercive public power to individuals, and could only be justified by public policies. Contract, that most "private" of nineteenth-century legal categories, was reconceptualized as simply a delegation of public power that could be justified only by public purposes. Fuller and Perdue's famous 1936 article on contract damages ${ }^{15}$ demonstrated that awarding damages for breach of contract could not be deduced from the "logic" of contract or from the will of the parties, but was a state-imposed sanction determined by the choice among policies. Shelley $v$. Kraemer ${ }^{16}$ is perhaps the most famous culmination of a generation of successful attacks on the public/private distinction.

By 1940, it was a sign of legal sophistication to understand the arbitrariness of the division of law into public and private realms.

13198 U.S. 45 (1905).

14 See, e.g., Cohen, Property and Sovereignty, 13 Corvel. L.Q. 8 (1927); Cohen, The Basis of Contract, 46 Hanv. L. Rev. 553 (1933); Hale, Force and the State: A Comparison of "Political" and "Economic" Compulsion, 35 Colum. L. Rev. 149 (1935); Pound, Liberty of Contract, 18 YALE L.J. 454 (1909). 15 Fuller \& Perdue, The Reliance Interest in Contract Damages (pt. 1), 46 YALE L.J. 52 (1936). 16334 U.S. 1 (1948). 
No advanced legal thinker of that period, I am certain, would have predicted that forty years later the public/private dichotomy would still be alive and, if anything, growing in influence. What accounts for its surprising vitality?

Until World War II, twentieth-century progressivism emphasized the role of the state in creating institutions that would promote a public interest. ${ }^{17}$ In reaction to the spread of totalitarianism, progressivism after World War II capitulated to the argument that any substantive conception of the public interest was simply the first step on the road to totalitarianism. ${ }^{18}$ The idea of a public interest thus came to be formulated in the purely proceduralist terms of interest-group pluralism-simply as whatever was the outcome of competition among interest groups. ${ }^{19}$ This was, it should be emphasized, a twentieth-century return to a market theory of the public interest-but this time the competitors were groups and the market was the political process.

Earlier, progressivism posited a sharp conflict between a substantive public interest and private self-interest, and regarded a primary function of the state as creating institutions that would transcend private self-interest. Unless the individualism and selfishness that was part of the culture of capitalism could be moderated, they believed, the system could not survive. Most of the Legal Realists operated out of this political paradigm and understood their task to be the moderation and limitation of private greed and domination.

But once the idea of a substantive public interest began to confront ridicule after World War II, the function of the state came to be redefined as simply a reflection of the sum of the vectors of private conflict. Private self-interest, which under the progressive program was to be kept suspiciously in check, once again became the only legitimate political reality, and the idea of an autonomous public realm began correspondingly to sink into oblivion.

The recent revival of natural-rights individualism in legal and political theory is a symptom of the collapse of a belief in a distinctively public realm standing above private self-interest. It is not only a dangerous symptom of the unravelling of all sense of community,

17 See J. Landis, The Administrative Process 10-16, 26-28, 98-99 (1938); Lewis, The "Consumer" and "Public" Interests Under Public Regulation, $46 \mathrm{~J}$. PoL. ECON. 97, 105 (1938).

18 See E. Purcelt, The Crists of Democratic Theorx: Scientific NaturatISM AND the PROBLEM OF VALUE 235-66 (1973).

19 Schubert, Is There A Public Interest Theory?, in The PuBric InTERest 162 (C.J. Friedrich ed. 1962); Sorauf, The Conceptual Muddle, in id. I83. 
but also a relapse into a predatory and vicious conception of politics.

Yet reality has a funny way of intruding upon theory. The public/private distinction could approximate the actual arrangement of legal and political institutions only in a society and economy of relatively small, decentralized, nongovernmental units. Private power began to become increasingly indistinguishable from public power precisely at the moment, late in the nineteenth century, when large-scale corporate concentration became the norm. The attack on the public/private distinction was the result of a widespread perception that so-called private institutions were acquiring coercive power that had formerly been reserved to governments.

The contemporary erosion of the public/private distinction in many areas of legal doctrine described by Professor Stone ${ }^{20}$ is but another symptom of the passing of that world of nineteenth-century decentralized competitive capitalism that once made that distinction a rough approximation of reality.

20 See Stone, Corporate Vices and Corporate Virtues: Do Public/Private Distinctions Matter?, 130 U. PA. L. REv. 1441 (1982). 